\title{
Thermochemical Treatment of Non-Ferrous Alloys
}

Pavel Novák, Pavel Salvetr, Adriana Bernatiková, Dalibor Vojtěch

University of Chemistry and Technology, Prague, Department of Metals and Corrosion Engineering, Technická 5, 166 28 Prague 6, Czech Republic, E-mail: panovak@vscht.cz

Even though the thermochemical treatment is thought as a typical domain of ferrous alloys, there exists a series of technically important processes in the case of non-ferrous metals. Thermochemical heat treatment processes can be divided to two main groups to the manufacture of wear resistant layers and the corrosion protection, mainly against the high-temperature corrosion. This paper summarizes current knowledge in this field and describes the realization of the processes and examples of practical applications.

Keywords: thermochemical treatment, titanium, aluminium, nickel

\section{Acknowledgement}

This research was financially supported by Czech Science Foundation, project No. P108/12/G043.

\section{References}

[1] DOBROCKY, D., KUSMIC, D. (2015). The Effect of Plasma Nitriding Process on the Change of Dynamic Parameters of steel DIN 1654/4. In: Manufacturing Technology, Vol. 15, No. 1, pp. 14-20. UJEP. Czech Republic.

[2] DOBROCKY, D., KUSMIC, D. (2015). The Assessment of Selected Mechanical Properties of Steel after Application of Plasma Nitriding. In: Manufacturing Technology, Vol. 15, No. 3, pp. 307 - 315. UJEP. Czech Republic.

[3] DOAN, V., KUSMIC, D., POSPICHAL, M. (2015) Surface Treatment Technologies for Wear Resistance Increasing of 42CrMo4 Steel, In: Manufacturing Technology, Vol. 15, No. 3, pp. 303 - 307. UJEP. Czech Republic.

[4] PILCH, O., SNAHNICAN, F., HRUBY. V., STUDENY, Z. (2015). The Effect of Plasma Nitriding Parameters on the Thickness of Nitrided Layers. In: Manufacturing Technology, Vol. 15, No. 5, pp. 885 - 889. UJEP. Czech Republic.2015, Vol. 15, No. 5, 885 - 889

[5] JAHNOVÁ, V., VOJTĚCH, D., NOVÁK, P., NOVÁK, M. (2004). Zvyšování povrchové tvrdosti titanu nitridací. In: Proceedings of Metal 2004, CD, Tanger, Czech Republic.

[6] GREDELJ, S., KUMAR, S., GERSON, A.R., CAVALLARO, G.P. (2006). Radio frequency plasma nitriding of aluminium at higher power levels. In: Thin Solid Films, Vol. 515, pp. 1480-1485. Elsevier, Netherlands.

[7] VOJTĚCH, D., KUBATÍK, T., PAVLÍČKOVÁ, M., MAIXNER, J. (2006). Intermetallic protective coatings on titanium. In: Intermetallics, Vol. 14, pp. 1181-1186. Elsevier, Netherlands.

[8] VOJTĚCH, D., NOVÁK, P., MACHÁČ, P., MORŤANIKOVÁ, M., JUREK, K. (2008). Protection of titanium by $\mathrm{Ti}_{5} \mathrm{Si}_{3}$ silicide layer prepared by combination of vapour phase siliconizing and heat treatment. In: Journal of Alloys and Compounds, Vol. 464, pp. 179-184. Elsevier, Netherlands. 